\title{
Herders And Farmers Conflict And Its Implication For The 2019 General Elections In Nigeria: What Can Public Relations Do?
}

\author{
Tyotom Keghku, PhD. \\ Kevin Alom, PhD \\ Department of Mass Communication \\ Benue State University \\ Makurdi, Nigeria \\ Joseph Dzerkaan Fanafa, PhD. \\ Deputy Director, Public Relations \\ University of Agriculture \\ Makurdi, Nigeria
}

\begin{abstract}
The paper analysed the herders and farmers' conflict and its implications on the forthcoming 2019 General Elections in Nigeria with focus on what public relations can do. The paper was anchored on the Dialectical Materialism Theory and supported by the Frustration Aggression Theory and Frank Jefkins Public Relations Transfer Process Model. The paper adopted survey research method to elicit data using interview as research instrument. Findings revealed that interethnic and intergroup conflicts have been on the increase since the evolution of democratic rule in 1999, and that the stakeholders meetings convened by the Federal Government of Nigeria are not all-inclusive but elitist. The paper recommended amongst others that the Federal Government should do more in curtailing the killings, destruction of properties and farmlands associated with the conflict and apply public relations strategies such such as dialogue, truth and full information, that the herders should establish ranches in order to curtain incessant conflict between them and farmers in line with best international livestock practice.
\end{abstract}

Keywords: Herders , Farmers, Conflict, General Elections, Public Relations.

\section{Introduction}

Conflict is a phenomenon that is an important part of human existence and a natural part of our daily lives. Conflicts could be seen as any personal divergence of interest between individuals or groups. Conflicts could also be referred to as behaviour intended to obstruct the achievements of the goals of other persons.

Conflicts could manifest in various forms; at home, work or while in transit or in governance and other areas of human endeavours. A conflict may occasionally become confrontational and culminate in physical violence. It can show itself through obvious enmity and hostilities between individuals or in dispute between organized groups of people.

Conflict may be easily recognized but not easy to resolve .Conflict is therefore natural in a healthy striving organization or human endeavour and such a scenario needs conflict but if that conflict is not recognized or managed then it can become destructive. In the past, conflicts were overlooked by behavioural scientists partly because it was felt that conflict was damaging to an organization and efforts should be concentrated on measures to create harmony at all times. Conflict is however now treated as an important aspect in the proper understanding of organizational behaviour. Keghku (2004, p.149) asserts in Nwosu and Wilson (ed) that "it has since been realized that not all conflicts are harmful and that perhaps a certain level of conflict is inevitable. The need therefore is to understand the cause of conflict and to develop constructive measures to control and use the energies realized by the conflict. In essence, conflict per se is not bad but it is the way it is managed to reduce its harmful effects and benefit from its good efforts as it applies to pernicious and positive propaganda in public relations parlance

Blench (2003) reports that the herders and farmers conflicts began at about the $20^{\text {th }}$ Century as a result of two major developments: the introduction of modern veterinary services leading to increase in herder sizes; and increased farming due to increasing population pressures. Blench (2010) also highlighted four major factors that affect conflict between herdsmen and farmers as: the collapse of the traditional system of cattle routes; the declining importance of dairy production; migration and disease; and the intensification of agriculture in riverine areas known as fadama cultivation. 
McGregor (2014) says that for decades now conflict between herdsmen and farmers has been a reoccurring issue in Nigeria most especially in the North Central States or Middle Belt region of Benue, Nasarawa, Plateau, Taraba and some parts of Kaduna State. In 2004, herders and farmers conflicts resulted into "near genocide" of Christians and Muslims in Plateau State, with more than 20, 000 refugees fleeing to neighbouring Cameroon .

In a report published by SMB Intelligence and cited in Amzat, Fagbemi, Wantu and Akinboye (2016) over 2, 000 people were killed in conflicts between the herdsmen and different host communities in Nigeria in 2015 alone. On February 24, 2016, Fulani herdsmen were reported to have killed over 300 people in Agatu community in Benue State and not less than seven local government Areas in the state were under siege as at March 2018; between February 2013 and January 2018, there are reports of 47 such attacks on the North Central region of Nigeria and over 5,000 deaths (Stefanos Foundation 2018). These attacks became so wanton and brutal that the 2015 Global Terrorism Index rated the Fulani pastoralists as the fourth most deadly terrorist group behind the Taliban, ISIL, Boko Haram in the world (Institute of Economics and Peace, 2015) as cited in International Journal of Media, Security, and Development(IJMSD), 2018, p. 13 .

The 2019 general elections in Nigeria are scheduled for February and March. In the light of the killings and displacement as outcomes of the conflicts, there are several refugees camps, especially in Benue State with hundreds of Internally Displaced Persons (IDPs). There has been massive destruction of properties - farmlands, foodstuffs, houses and livestock, and other means of livelihood, what does the above portend for the 2019 general elections in Nigeria? The 2019 elections are critical for Nigeria as they involve the President, Senators, House of Representatives and Governors in over 33 of the 36 states. When people, that is, the electorates, are traumatized, insecure and not sure of the basic needs of life, it becomes an abnormality to talk about elections. Campaigns have already started, to terminate before the elections but over 20 million people in the volatile states of Benue, Delta, Nasarawa, Kaduna, Plateau, Taraba the Federal Capital Territory, Abuja, Ondo ,Edo, Enugu and even Zamfara (where rampant cases of cattle rustling and armed banditry are the norm) are to some extent caged and are likely not to participate fully and enthusiastically in the 2019 general elections. This scenario beckons on public relations as a profession to come to the rescue, if the elections are to be rancor- free. Managing conflicts is one of the challenging areas of public relations practice. Managing of conflicts is achievable through the establishment of two -way communication to resolve the conflict or areas of mutual misunderstanding, apathy and establishment of understanding based on truth, knowledge and full information.

\section{Statement of Research Problem}

The herders and farmers conflict in Nigeria has become recurring decimal. The cause can be ascribed to control over land for grazing and farming, massive desertification of vegetative lands and droughts in Northern Nigeria which compel herders to migrate towards the middle belt region and some parts, of the south in search of greener pasture and water for their livestock. In the course of their movement, the nomadic herdsmen settle in farming communities where there is green vegetation and water such as within the Benue valley/tough. Often times, farmers accuse the herdsmen of encroaching and destroying their farmlands and crops and contaminating their main source of water supply. The herdsmen on their part accuse the farmers of poisoning, killing or even stealing their livestock especially cattles. The herdsmen also accuse the farmers of blocking their grazing routes, alleged to have been established in the early 1960s. The herdsmen and farmers conflict has assumed mere worrisome dimension with the use sophisticated weapons such as AK47 by the herdsmen who were known for the use of sticks and cutlasses while grazing. Regrettably, the conflict has even defied security measures by the Federal Government of Nigeria. Several farming communities in several States of Nigeria have suffered unrelenting attacks for quite some years. The 1999 Constitution of the Federal Republic of Nigeria, as amended in Chapter II Section 14 Subsection2 (b) clearly states that 'The security and welfare of the people shall be the primary purpose of government'. The spirit of the constitution as mentioned above has not been adhered to. It is on record that in a single attack of herdsmen on farmers on January $1^{\text {st }}, 2018$, in Benue State alone, 73 victims were killed and buried enmass (The Nation Newspaper, January 11, 2018.).

These nomadic herdsmen mostly migrate in the dry season in search of the greener pastures. The fact remains that the rearing of livestock is a business just like farming is also the main occupation of the host communities. The herds men are against ranching as provided for in enabling laws by the governments of Benue, Ebonyi and Taraba States. These laws are in conformity with standard global best practices in livestock management. As the 2019 General Election in Nigeria draw close, the effects of the herders and farmers conflict could be disenfranchisement of the electorates from voting the candidates of their choice. Some displaced families and communities who lost their Permanent Voters Card (PVCs) will not vote for candidate of their choice in the elections. Public relations holds a central position in the overall outcome of a conflict given its power of meaningful dialogue based on correct and full information. Consequently, this paper seeks to investigate the role of public relations in mitigating the recurring herdsmen and farmers conflicts. 


\section{Objectives of the Study}

The broad objective of this study is to highlight the role of Public relations in the recurring herdsmen and farmers conflict while the specific objectives are:

i. To determine the application of public relations strategies by the Federal Government in resolving the conflict.

ii. To establish which public relations strategies are being adopted by the Federal Government in resolving the conflicts.

iii. To assess the level of awareness of the public relations strategies by the herdsmen, farmers and other relevant stakeholders.

iv. To examine the extent of successes or otherwise of the public relations strategies adopted by the Federal Government in resolving the conflicts.

\section{Research Questions}

i. How do you determine the application of public relations strategies by the Federal Government for resolving the conflicts?

ii. What are public relations strategies being adopted by Federal Government in resolving the conflict?

iii. What is the extent of awareness of the public relations strategies by herdsmen, farmers and other relevant stakeholders?

iv. What is the extent of successes or otherwise of the public relations strategies adopted by the Federal Government in resolving the conflict?

\section{Scope of the Study}

This study focuses on the role of public relations in resolving the persistent herders and farmers conflict in Nigeria in general and Benue State in particular. This is with particular reference to the implication of the conflict to the forthcoming General Elections in Nigeria.

\section{Operational Definition of Key Terms}

Conflict: Conflict is a continuing feature of social existence. It is not the absence of conflict that marks out a great nation but the manner in which conflicts are resolved. Conflict is a situation of disagreement or incompatibility between two parties characterized by the inability of those concerned to iron out their differences. In this study, conflict is the outcome of opposing or opposed interests, concerns and needs of Fulani herders and farmers over grazing of their cattle on the latter's farmlands

Public Relations: According to Keghku 2005,p.6 'public relations is the process of making known and acceptable , an organisation's policies, programmes and actions through effective communication for the overall mutual benefit of the organization and its target publics'. Public relations, in this paper, is the effective management of the herders and farmers conflict through appropriate strategies, based on facts, truth and full information

General Elections: Elections of the President and his Vice, Members of the National Assembly, that is the legislative arm of Government, comprising Senators and Members of House of Representatives, and State Governors are to be conducted by the Independent National Electoral Commission(INEC) in February and January, 2019. In this work, the forth coming elections is for the electorate to elect their leaders at the Federal and State levels

Herders: These are nomadic pastoralists who are mainly Fulanis, one of the ethnic groups in Northern Nigeria. Their main pre-occupation is rearing of livestock (cattle, sheep and donkey)

Farmers: Farmers in Nigeria are found in every part of the country. Most Nigerians are farmers-small scale (peasant) farming or large scale. Farmers till the land and cultivate all kinds of crops for either cash or consumption. Farmers belong to virtually all ethnic groups in Nigeria

\section{Literature Review}

Available records indicate that quite a number of researchers in diverse fields have addressed the issue of conflicts and possible solution generally. In the words of Stern (1998) and Akorede (2005), conflicts are natural parts of life. Both scholars aver that conflict is a by-product of the interaction of people or groups with different expectations, interests and backgrounds in the society. This position aptly agrees with the herders and farmers conflict situation in Nigeria. The herders' background, expectations and interests are no doubt, at variance with that of farmers in Nigeria. They are therefore, continuously to achieve their interest and expectations by attacking the peasant farmers in the course of grazing their herds.

Shadrach (2016,p.25) captures it graphically that: 
The fact cows began to be slim, there was no more water for them to drink and for the love of herd, the herdsmen began to work down towards central Nigeria (Middle Belt), by the time they reached Plateau, Taraba and other Middle Belt states, they began to see fresh green grass and water.

This naturally, brings the herders into conflict with the farmers whose crops and fertile farming land is now endangered by the arrival of the herdsmen. Many scholars, (Isard 1992, Otite 1999, Weck 1992 and Jibo 1993), groups and/or organizations such as Amnesty International(AI) and International Crisis Group (ICG) all over the world are concerned and worried about conflict generally. They also indicate worry and concern over the issue of the conflict between herders and farmers in Nigeria and the implications. Somehow, the emerging debate on the matter is seen to be based on certain assumptions and these assumptions appear to be the opinions of very many scholars. They all appear to agree to the assumption that conflict is a natural and inevitable phenomena that is an important part of human existence. Isard (1992, p.1) says it is a "natural part of our daily lives". Weck (1992, p.9) affirms "it cannot be excluded from social life." Emerging from this same assumption that conflict is inevitable and ubiquitous, Yecho (2006, p. 115) agrees that "contemporary world is built around conflict".

Other scholars ,Simons, (1979) and Sorkaa,( 2006) also agree that conflict and disagreements are the same phenomenon. Simon (1979) particularly notes the extensive use of the term "communication breakdown" to describe conflict situation. Though conflict tantamount to disagreement, conflict in real sense, is more serious than mere disagreement and deserves more serious attention.

Another assumption is that conflict is dynamic, not static. Here, Lederach in Mamkaa(2018) insists that conflict is a static phenomenon, but expressive, dynamic and dialectical. Best (2006, p. 65) argues that "each conflict has its dynamics, characterized by different stages and phases of change and transformation". This assumption could be useful in addressing issues of conflict by isolating particular conflict, with its peculiarities, to deal with rather than giving up that it is inevitable, therefore cannot be resolved and should just be accepted as such. The assumption often appear to erroneously inhibit the mindset of the authorities from acting decisively in tackling conflict especially as it concerns the herders and farmers conflict in Nigeria.

Whatever assumptions, it is worthwhile to note that most often than not, conflict is, in the words of an early conflict theorist, Coser (1965), cited by Mamkaa(2018) posits that the struggle over values and claims to scarce status, power and resources in which the aims of the opponents are to neutralize, injure, or eliminate the rival's. This fits the herders and farmers conflict in Nigeria as the herders appear to be on the constant struggle over the scarce arable farmlands of the farmers, with the aim of eliminating them. Meanwhile, Nigeria has scheduled general elections to hold in February and March 2019. The elections are to put in place the executive and legislative arms of government at the national and state levels. In other words the general elections will involve the entire citizenry of the country including Plateau, Nasarawa, Taraba States where conflict exists. The implication is that several people are certain to be disenfranchised, very many are displaced, some have lost their voters registration card, and others could not register. There is serious animosity, lingering sense of insecurity and palpable fear. To restate the obvious here, there can hardly be any free and fair elections in the midst of chaos, rancor and conflict within concerned citizens. The implications of the herders and farmers conflict on the general elections are therefore far-reaching and deserve urgent attention.

Reports abound on the herders and farmers conflict in Nigeria. In a recent report chronicled by Nzechi, Onani and Anule (New Telegraph, Dec. 2018), Amnesty International stated that between Jan. 5, 2016 and October 5, 2018, not fewer than 3,641 lives were lost in Nigeria. In the report captioned, "Harvest of Death: Three years of Bloody Clashes Between Farmers and Herders" the organization stated that 57 percent of the deaths occurred in the year 2018 alone. According to its Director in Nigeria, Osai Ojigho the herders attacks on the farmers were well planned and coordinated with the use of weapons like machine guns and AK47 rifles, it however appears little has been done by the authorities in terms of prevention, arrests and prosecutions, even when information about the suspected perpetrators was available". It blamed the incessant bloody attacks and high casualty figures on the failure of the government to investigate the communal clashes and bring the perpetrators to justice. In yet another report, (Premium Times, December 17, 2018) captioned "Nigeria: How Nigerian Government's Failures Fuel Farmers Herders conflict causing nearly 4000 deaths, another gloomy picture was presented. The International Criminal Court, ICC, independent body said it was examining farmers-herders crisis in Nigeria. The Lead Prosecutor of the ICC, Fatau Bensoula is quoted to have disclosed this in The Hague, Netherlands, while presenting the annual report of the ICC activities in the year 2018, on Wednesday, Dec. 26, 2018. He said the ICC was examining information to determine where there are reasonable basis to believe that the crimes allegedly committed fall under its jurisdiction (Premium Times). 
Another international independent Organization, International Crisis Group, ICG, in a published report, (Pulse, Nigeria, July 2018), pointed out that violence between Nigerian herders and farmers has escalated, killing more than 1,300 people" within seven months of the year 2018. According to ICG, the conflict has "evolved from spontaneous reactions to provocations and now to deadlier planned attacks particularly in Benue, Plateau, Adamawa, Nasarawa and Taraba states. The farmers-herders attack has become Nigeria's gravest security challenge now, claiming far more lives than the Boko Haram insurgency". Same report quoted by the (Vanguard, July 26, 2018) raises alarm that "worsening violence between farmers and herders could hit Nigeria's general elections and distabilise the country.

The election threatening scenario is captured by the mass media across the globe. Washington Post, (December 10, 2018) and the Punch Newspaper (December 24, 2018), lament variously; 'Osun NSCDC settles 100 cases of farmers/herders dispute' and 'ordinary people keeping the peace in Nigeria deadly land feuds'. All these are indications that the conflict may have implications for the the country's general election scheduled for February and March 2019. Deliberate, planned and sustained efforts are required to tackle the situation. This paper is of the strong view that the needed efforts can best be provided by public relations professionals.

The position is premised on the fact that public relations is, according to the popular Mexican Statement 1978;

The art and social science of analyzing trends, predicting their consequences counseling their organization's leadership and implementing planned programmes of action which will serve both the organizations' and public's interest (Ajala, 2005, p.13).

Public relations is a form of communication that aims at gaining mutual understanding. It aims at achieving some sort of commonality of interests between organizations and its publics. In other words, it normally seeks to achieve a harmonious co-existence. Keghku in Nwosu and Wilson (2011) further stresses that public relations is a two way communication to resolve conflict or areas of mutual interest and the establishment of understanding based on truth, knowledge and full information. . Black (1989) asserts that public relations is the establishment of a two-way communication to resolve conflict of interest. From the foregoing public Relations as a profession is the most suitable in mitigating the conflict among herders and farmers to create the needed harmony and tranquility required to achieve credible elections.

In addressing the application of public relations generally, Newsom, Turk and Kruckeberg (2004) observed that the most valuable public relations activity is that which plans to prevent problems or at least solve them, while they are small”.

Ajala (2005) and Keghku (2005) both advanced strategies and measures that public relations could adapt to handle conflict, crisis or any disharmonious situations. They advise that organizations or government in this case can employ the services of public relations professionals to handle the herders and farmers conflict in Nigeria. Ajala (2005) says, public relations, no doubt, has a critical role to play to assist government in addressing conflict, and the "government must address challenges, including the conflict in the country, using the public relations approach to achieve lasting solutions. Keghku (2005) points to the fact that public relations techniques are useful in resolving conflict and averting total breakdown of law and order.

\section{Empirical Review}

In his study; Comparative, Analyses of Communication, Techniques Used Around the World in Conflict Resolution: Lessons from Multiethnic Societies, Ikpah (2008) avers that communication is strategic in conflict resolution. Ikpah, citing several conflict situations around the world including the conflict between the state of Israel and the Hezbollah, the Pridnesetrov conflict situation and the Romanian Peace Action, Training and Research Institute (PATRIR) approach and the Nigeria oil conflict situation among others, submits largely that communication, not violence, is the best approach to handling conflicts.

In the case of "How Nigeria miraculously defeated Ebola with effective communication in 93 days, Ayodele (2017) affirms that public relations approach was applied, using effective communication strategies. The reported that the strategies employed were; breaking the news early, a robust contact tracing system, massive public awareness campaign, effective utilization of the power of the social media, regular update, closing and strict supervision of borders, training, strategic partnership to establish operations centres and leveraging on existing techniques and infrastructure. This approach put government in good stead and within 93 days, the dreaded Ebola was completely eradicated.

Another case of public relations strategic communication by Ayodele (2017) is "How Lifebuoy's strategic communication reduced infant mortality in India. Lifebuoy is the world's number one selling anti-bacterial soap produced by Unilever and marketed in nearly 60 countries. The challenge was that, every year two million children die before they reach the age of five due to diarrhea and pneumonia. 
Times of India reports that $20 \%$ of the world's under 5years deaths occur in India. The Lifebuoy's innovative Public Relations Strategy was applied using the "Help a child reach 5" idea in Thesgora village with high rate of such deaths. The results was marvelous. It helped reduce diarrhea in Thesgora village by $75 \%$. By the year 2017, the campaign got 37,000 likes on Facebook, 790 comments, 110 replies on Twitter and 1,451 likes as well as garnered 16 million pledges. The impact and result were spontaneous.

\section{Theoretical Framework}

Two theories were used for the study and a model:

i. Dialectical Materialism Theory

ii.Frustration Aggression Theory

iii.Public Relations Transfer Process Model.

The paper is anchored on the Dialectical Materialism Theory of Karl Marx (1818-1883) which maintains that conflicts result from man's consciousness of himself and material conditions existing in the society. The theory postulates that man attaches great importance to what he possess or what he can call his own in the society. That is, that life is determined by social or economic production. In other words, what is produced, how and who produces it, how that which is produced is shared; material possessiveness.

In analyzing the application of the theory to his study, Vaaseh in Wuam and Ikpanor (2013) aver that since the resources are unevenly distributed or are naturally scarce, the struggle over their possession usually brings conflicts. This aptly fits in these situations of herders and farmers conflict. While farmers lay claim to those limited rich vegetation lands of the Central and Southern Nigeria and try to hold tight onto the lands for farming, the nomadic herders who lack same in most of the northern parts of the country from where they come turn to struggle over them with the farmers for the grazing of their herds. The result is the conflict that ensues, with both parties trying to possess the land and enhance their means of production and livelihood.

Secondly, the paper is supported by the Frustration Aggression Theory, propounded by Dollard and Associates in and later expanded by Yates and Berkwonitz 1960 and 1962 respectively.

This theory maintains that the scarce resources remain and the quest to acquire or even takeover control exist, the farmers who feel challenged get frustrated and attempt to resist in defence while those herders also feel frustrated too as they apparently don't see better alternatives. Both parties are frustrated. Consequently, the Frustration Aggression Theory applies. In either case, there must be deliberate efforts to ensure harmonious co-existence in the event where the conflict has already created some level of hostilities, apathy and/or total disharmony.

Thirdly, the paper is supported by the Public Relations Transfer Process Model developed by Frank Jefkins in 1989.

The model posits that public relations is an effective communication profession, which techniques can help transfer a crisis situation into a peaceful one and a negative situation to a positive situation. Frank Jefkins succinctly captures public relations role as achieving sympathy where there is hostility, acceptance in place of prejudice, interest for apathy and knowledge for ignorance.

Frank Jefkins Public Relations Transfer Process Model

Negative Positive

Hostility Sympathy

Prejudice Acceptance

Apathy Interest

Ignorance Knowledge

Source: Frank Jefkins ,1998

The significant or relevance of these theories is that both clearly bring to the fore the underlying motives for the prevailing conflict between herders and farmers in Nigeria and, the Frank Jefkins Public Relations Transfer Process Model fits in for the purpose of achieving positive situation in the conflict. Whichever approach employed to redress the situation, such approach must be deliberate, planned and sustained. This is the preoccupation of public relations as a profession, toward achieving harmony or mutual understanding.

\section{Research Methodology, Population and Sample}

The choice of research method for any research undertaking is usually guided by the nature of the research problem and objectives. For a study which involves meeting people in their natural settings to elicit their opinions and views on a crucial public issue like this one on the Public Relations role on herders and farmers conflict and its implication for the 2019 general elections in Nigeria, the most suitable method is naturally survey. 
Survey research has those right attributes that will allow for guided, systematic and objective collection of the needed data and statistics. Survey is the specification of procedures for gathering information about a large number of people by collecting information from a few of them (Barran 2004). Against this background, attempt was made to identify, examine, explain and establish casual relationship between farmers and the herders violent areas. The deployment of this method helps the study to identify and explain the frequency of occurrence of and changes in farmers and herders attitude, beliefs and behaviour towards land-based resources and their utilization. It also assesses differences between the farmers and herders in their attitudes, beliefs and behaviour towards the research problem.

For a more focused and result-oriented study, the population is the entire Benue State with the projected figure of 7million people,NBS (2018) . Their choice was not only aimed at overcoming certain research constraints like time, logistics, manpower and other human induced elements, but also to attain benefits that would accrue from a costeffective approach to the study. This cannot be attainable if a sort of blanket study involving a large geographical area like the whole country or an entire geographical zone is used.

In line, the selection of a manageable sample was done using stratified sampling method. To achieve this, the chance was there for an appropriate audience/respondents likely to respond accurately in accordance with the objectives of the study. Thus, we were afforded the opportunity of dealing with a sample representative of the entire population. This is because it encompassed a variety of people with diverse demographic and psychographic attributes, as obtainable in the entire universe.

\section{Data Collection and Analysis}

For the collection of requisite relevant data for the study, interview was employed. It involved the drawing of set of questions based on the objectives and research questions of the study. The method afforded us opportunities of explaining some aspects not so clear to some interviewees/respondents like the less informed or enlightened. The views and opinions expressed by the interviewees were therefore subjected to critical analysis. In doing this, descriptive statistics elements were found effective and used. The procedure led to appropriate interpretation of data in relation to the research questions, hence reflecting the findings and attitudes of the respondents to the research subject.

\section{Discussion of findings}

The result of data collected from interviewees revealed that Herders and Farmers conflicts in Nigeria particularly Benue state which is the focus of the study are not only alarming and ubiquitous but worrisome. However, contemporary trends in Nigeria as a whole, have shown that incessant farmer-herder conflicts are not only a peculiar characteristics of the state.

It was also found by the study that though, Tiv land like other ethnic groups/nations in the North Central Nigeria has witnessed group conflicts and violence before 1999, and violent inter-group clashes have been on the increase since the environment of democratic rule in the country on $29^{\text {th }}$ May 1999.

Interestingly, the study discovered that since Nigeria's independence in 1960 , arable land in the country has been shrinking as a result of over-use, misuse, population growth and/or desertification. This has been a major cause of farmers-herders conflicts in Benue State in particular and Nigeria in general. This finding agrees completely with the submission by Gundu (2017) in Mamkaa (2018) that in 1961, Nigeria had 0.51 hectares of arable land per person. In 1990, the figure shrunk to 0.29 hectares per person. In 2010, it was 0.21 hectares per person; at current growth rate it will shrink to 0.17 hectares per person in 2020, 0.13 hectares per person in 2030, 0.10 hectares per person in 2040 and 0.8 hectares per person in 2050 .

Clearly, from this analysis the idea of creating grazing reserves is unthinkable as there is little arable land and in the near future, there will be no tract of land anywhere in the country for grazing reserves and cattle routes for herdsmen. This study has also established that the herders attacks on farmers in Benue State have caused physical, material and psychological damage to both parties. These findings, to a large extent, have agreed with the findings of other scholars, Awogbade (1987); Jibo (1993); Genyi 2014). In their separate studies, these scholars have found that violent clashes between farmers and herdsmen in Nigeria seriously damaged agriculture (the mainstream of the Tiv economy) and its appendages. The consequences of this is the challenge on socio-economic development faced by the Benue people with the destruction of public infrastructure and livelihood. Another finding revealed that the only public relations strategy adopted by the Federal Government of Nigeria is the convening of stakeholders meeting. But it has been discovered that such meetings are not all inclusive, are rather elitist.

\section{Conclusion}

Based on the data collected and analysed in this paper, the study concludes that ethnic and religious identities have received a predominant share of responsibility for internally instigated conflicts in Nigeria. 
The conflict between the farmers and herders in Benue state is primarily, rooted in the contestation for land, pasture and water. The trespassing on farm lands by the Fulani cattles takes two dimensions, the cramping of the soil, which makes cultivation using traditional means of tilling extremely difficult, and the destruction of the crops and farm produce. Little or no access to pipe borne water and/or borehole has forced rural farmers to resort to water from streams, rivers or ponds for drinking and other domestic uses. The contamination of these sources of water by Fulani cattle through direct consumption and excretion while walking through the water, makes the water dangerous for human consumption. Attempts by the farmers to resist acts these provocative acts are often repelled by the herdsmen and hence, the eruption of the deadliest clashes between these two groups in Nigeria.

\section{Recommendations}

Having critically examined the farmers-herders conflict in Nigeria and its implication for the 2019 general elections, the fundamental transformation being sought is to induce pastoralists to abandon a transhumant life-style in favour of becoming sedentary livestock producers. This is a stabilized ranch system. Cattle rearing as a way of life or trade business, is not unique to Nigeria. Over the years, all countries that have large herds of cattle have had this kind of farmers-herders confrontations. Such countries (the five top cattle producers worldwide) include; India with 219 million, Brazil 170 million, china 106 million, USA 96 million and Argentina 50 million. It is therefore recommended that in other to curtail these incessant conflict, there is a need for herders to establish ranches.

Furthermore, ranches will lead to the modernization of animal husbandry practice; promote job and investment opportunities; manage the environmental impact of open livestock grazing; prevent, control and manage the spread of diseases as well as enhance the production of high and healthier livestock for both local and export market; promote the establishment of international best practices in the dairy/beef industry; prevent the destruction of crop farms and ponds or wells by open grazing of cattle; and above all, prevent clashes between herders and farmers.

Government at all levels should urgently improve water supply for farmers and herders to reduce and perhaps, prevent hostile competition over water and its sources by these two groups of agriculturists, government should drill more boreholes and repair the damaged ones as well as build dams across rural areas in the country.

The paper recommends that adoption of more public relations strategies such as: regular advocacy meetings with all relevant stakeholders, effective media relations and dissemination of truthful information which eliminate hate speeches.

Above all, the paper recommends he need for deliberate, planned and sustained relationship between herders and farmers which should be promoted by all relevant authorities in Nigeria.

\section{References}

Ajilore, K. and Olomojobi,O.(2017). Ploughshares into Swords: National Newspapers Framing of the Conflict between Herdsmen and Farmers in Nigeria. International Journal of Media, Security and Development(IJMSD) 4(1),12-12

Amzat,A., Fagbemi,A., Lawal,I., Wantu,J. \& Akingboye,O.(2016) Menace of Fulani Herdsmen versus Host Communities. The Guardian Newspaper, January 8,p. 12

Ajala, V. O (2005), Public Relations In search of Professional Excellence. Ibadan: May Best Publications.

Akorede, Y.O. (2005). "Women and Intra Gender Conflict in the African Narratives" unpublished Ph.D thesis submitted to department of communication and languages Arts University of Ibadan.

Ayodele I. (2017), PR Case Studies: Mastering the Trade. Badagry-Lagos: Bezit Global Link Ltd

Awogbade,M.(1987) 'Commission on Nomadic Peoples: Grazing Reserves in Nigeria' in Journal of Nomadic Peoples (1) $14-28$

Bawan, S(2004) introduction to mass communication, media literacy and culture $3^{\text {rd }}$ editions. New York: McGraw-Hill companies

Blench,R.(2003). Transformation of Conflict between Pastoralists and Cultivators in Nigeria. RetrievedonNovember20,2018from http://www.rogerblench.info/conflict/herderfarmer\%20conflict\%20 in \% Nigeria.pdf

Blench,R.(2010). Conflicts between pastoralists and Cultivators in Nigeria,DFID UK

Best,J. (2006), The Political Dimension of Conflict in Benue Valley Guse and Ajene (eds) Conflicts in Benue Valley. Makurdi: BSU Press.

Black, S. (1989) Introduction to Public Relations. London: the Modino Press Ltd. 
Genyi,G.(2014) 'Ethnic and Religious Identities Shaping Contestation for Land Based Resources: The Tiv Farmers and Pastoralists Conflicts in Central Nigeria', paper presented at the First Annual International Conference on Ethnic and Conflict Resolution and Peace Building. New York City.www.icem.org

Gundu (2017) Opening Remarks presented at an International Conference tittled 'Herdsmen and Farmers Conflict': Learning from the Past, Organised by the Centre for Research Management held at the Benue State University on the 14-15 March,2017.

Ikpah, M. (2018), Comparative analyses of communication techniques used around the world in conflict resolution: lessons for multiethnic societies. A paper presented at Africa Council for Communication Education in Nigeria, August 6-8 at Aberaka. Delta State, Nigeria.

Isard, W. (1995), Understanding Conflict and Science of Peace. Cambridge MA: Blackwell.

Jibo, M. (1993), Tiv Politics Since 1959. Katsina Ala: Mandate International.

Jibo,M.(1993) Tiv Politics Since 1959.Katsina-Ala: Mandate International

Keghku, T. (2005), Public Relations and the Nigeria Economy. Makurdi: Aboki Publishers.

Keghku,T.(2004). Public Relations and Conflict Management: An Overview in Nwosu,I.E. \& Wilson,D Communication, Media and Conflict Management in Nigeria, Enugu:ACCE Nigeria Chapter

Keghku,T.(2005). Public Relations and the Nigerian Economy,Makurdi: Aboki Publishers.

Lederach (1990), in Marami, Unpublished Ph.D Thesis submitted in the Department of Political

Sciences, Benue State University, Makurdi.

Mamkaa,I.(2018) Farmers- Herders Conflict and Socio-Economic Development in Tivland, Unpublished Ph.D Thesis submitted to the Postgrduate School, Benue State University.

Mojaye,E.M., Aihagba,E., Soola,E. \& Oso,L.(2008). Media, Dialogue, Peace Building and Reconciliation Conference Procedings, Abraka: ACCE, Delta State.

McGregor,A.(2014) Alleged Connection between Boko Haram and Nigeria's Fulani Herdsmen could spark a Nigerian Civil War. Terrorism Monitor, 12(10), 8-10

National Bureau of Statistics(2018) www.population.gov.ng and www.Nigeriastate.gov.ngRetrieved on December 2,2018

Newson,D.,Turk,J.V. and Kruckeberg,D.(2004) This is PR: The Realities of Public Relations.Belmount,CA: Thomson/Wadsworth.

Newson, L. and Scolt, (1998), This is Public Relations: The Realities of Public Relations. California: Wadsworth Publishing.

Nzeshi, Onani and Anule, (2018), New Telegraph, December 18, 2018

Otite, O. (1992). The Eight Essential Steps to Conflict Resolutions. New York: Putnan Tharcher.

Premium Times, December 17, 2018. http://www.premiumtimes.ng.com

Pulse, Nigeria. https://www.pulse.ng

The Punch Newspaper, December 24, 2018. http://www.punchng.com

Sorkaa A. P (2003). Development as Ethics and Accountability in Governance. The Way Forward for Nigeria. Makurdi: The BSU Press.

Shadrach, L.T. (2016). Responding to Herdsmen Assaults. Makurdi: Southern Enterprise and Publishers.

Simons, H.W. (1979), "The Management of Metaphor "A Paper Presented at ASILOMAR, $79^{\text {th }}$ Conference on Human Communication from International View. Asitomar, CA.

Stern, M. (1991). Understanding Organizational Behavior. Boston: Kent publishers.

Stefanos Foundation(2018) President Muhammadu Buhari's War on Terror from June 2015 to 2018. State of the National Security

Vanguard Newspaper, July 26, 2018. http://www.vanguard.ng.com

Wuam, T. and Ikpanor, E. T (2013). The Military Invasion of Zaki-Biam. Makurdi: Aboki Publishers.

Yecho (2006), An Overview of the Tiv-Jukun Conflict in the Benue Valley in Guse and Ajene (eds) Conflicts in Benue Valley. Makurdi: BSU Press. 